\title{
KONSTRUKSI REALITAS SOSIAL DAN MAKNA DIRI PENYINTAS COVID-19 DI JAKARTA
}

\author{
Vina Apriani ${ }^{1 *}$, Wahyu Utamidewi², Nurkinan ${ }^{3}$ \\ ${ }^{1,2,3}$ Universitas Singaperbangsa Karawang, Indonesia \\ *vinaapriani749@gmail.com
}

\begin{abstract}
The Covid-19 pandemic has a major impact on people's lives in Indonesia. The impact felt by the community is not only in the economic, educational, cultural sectors, but also in social interaction patterns. The aim of this research looks at the diversity of experiences and self-meanings of the Covid-19 survivor through social reality construction theory. It has an effect on change in social interactions that occur in the current era and in future lives. This study took the subject of 5 Covid19 survivors living in Jakarta. Jakarta was chosen by researchers because that has the highest rate of Covid-19 cases in Indonesia. This study uses the theory contruction of social reality because this theory is in accordance with the research objectives. This theory is formed from a society that acts as a victim as well as a perpetrator in social construction and become to a social reality. This study uses the phenomenological method because it looks at the social actions taken by an individual with Covid-19. The data collection technique in this research is interviews with in-depth interviews. The results of this study are that the self-meaning of Covid-19 survivors in Jakarta is categorized into five, namely: a) Closed; b) Fear; c) Self-regret; d) Confused; e) Trauma. These five meanings are formed based on communication experiences faced by present and past survivors so that a construction of these meanings is formed.
\end{abstract}

Keywords: phenomenology; covid-19 disease; self meaning; construction of social reality

\begin{abstract}
Abstrak
Pandemi Covid-19 memberikan dampak yang besar terhadap kehidupan masyarakat di Indonesia. Dampak yang dirasakan oleh masyarakat tidak hanya dalam sektor ekonomi, pendidikan, budaya, namun juga pola interaksi sosial. Tujuan dari penelitian ini adalah untuk melihat adanya keberagaman pengalaman dan makna diri dari para penyintas Covid-19 melalui teori konstruksi realitas sosial. Hal itu berpengaruh terhadap perubahan interaksi sosial yang terjadi diera saat ini dan kehidupan mendatang. Penelitian ini mengambil subjek para penyintas Covid-19 yang tinggal di Jakarta sejumlah 5 orang. Kota Jakarta dipilih oleh peneliti karena Jakarta merupakan salah satu kota yang memiliki tingkat kasus Covid-19 tertinggi di Indonesia. Penelitian ini menggunakan teori kontruksi realitas sosial karena teori ini sesuai dengan tujuan penelitian. Teori ini terbentuk dari masyarakat yang berperan sebagai korban sekaligus pelaku dalam konstruksi sosial dan melahirkan suatu realitas sosial. Penelitian ini menggunakan metode fenomenologi karena melihat tindakan sosial yang diambil oleh seorang individu penyintas Covid-19. Teknik pengumpulan data dalam penelitian ini adalah wawancara dengan in depth interview. Hasil penelitian ini adalah makna diri penyintas Covid-19 di Jakarta dikategorisasikan menjadi lima, yaitu : a) Tertutup ; b) Ketakutan ; c) Penyesalan diri; d) Bingung; e) Trauma. Kelima makna ini terbentuk berdasarkan pengalaman komunikasi yang dihadapi penyintas di masa sekarang dan masa lalu sehingga terbentuklah sebuah konstruksi makna tersebut.
\end{abstract}

Kata Kunci: fenomenologi; penyintas covid-19; makna diri; konstruksi realitas sosial 


\section{PENDAHULUAN}

Pada tahun 2019 Indonesia mendapatkan musibah yang juga dialami oleh hampir seluruh negara, yaitu wabah penyakit Covid-19. Awal mula pandemi Covid-19 muncul pertama kalinya di Kota Wuhan China tepatnya di pasar hewan dan makanan laut di akhir Desember 2019 lalu. Seperti yang dikutip dari $B B C$, koresponden kesehatan dan sains $B B C$, Michelle Roberts and James Gallager menuliskan bahwasanya pasien yang mengalami virus corona memiliki keterkaitan dengan pasar hewan serta makanan laut yang terdapat pada pasar tersebut (Hong, 2020).

Negara China adalah negara yang pertama kali dilaporkan adanya kasus Covid-19 ini. Di ujung tahun 2019, (WHO) organisasi kesehatan dunia mengatakan bahwa di negara China terdapat kabar mengenai hadirnya sejenis pneumonia yang tidak ditemukan penyebabnya. Virus ini menyerang paruparu dan mengakibatkan infeksi pernafasan yang serius. Menurut pihak yang berwenang, sebagian pasien tersebut adalah pedagang yang bekerja di pasar ikan Huanan (Sukur et al., 2020).

Penyebaran COVID-19 pertama kali di negara Indonesia secara resmi diumumkan pada tanggal 2 Maret 2020 oleh Pemerintah. Hal tersebut diduga karena ada dua warga negara Indonesia yang dinyatakan positif setelah berinteraksi langsung dengan penduduk negara Jepang yang tengah berkunjung ke Indonesia. Korban jiwa akibat COVID-19 pertama kali terjadi tanggal 11 Maret 2020, seorang laki-laki berusia 59 tahun yang berasal dari Solo. Ia tertular setelah mengikuti seminar di Bogor pada bulan Februari. Penyebaran virus Covid-19 di Indonesia ini sudah menyebar ke seluruh pelosok provinsi (Sukur et al., 2020).

Kota Jakarta merupakan kota yang memiliki tingkat kasus Covid-19 tertinggi di Indonesia. Berdasarkan Data
Pemantauan Covid-19 DKI Jakarta melalui laman corona.jakarta.go.id, pada tanggal 24 Maret 2021 kasus Covid-19 di Jakarta dilaporkan 372.871 kasus positif. Sebanyak 360.479 kasus sembuh, 6.206 kasus meninggal, 3.079 kasus sedang dirawat dan 3.107 isolasi mandiri (Pemerintah DKI Jakarta, 2021). Terdapat jumlah peningkatan stigmatisasi public kepada orang-orang yang berasal dari derah yang terkena epidemi.

Meningkatnya kasus Covid-19 di Indonesia memberikan dampak yang cukup serius pada tatanan negara terutama kesehatan, pendidikan, perekonomian dan kehidupan sosial. Pada sektor ekonomi dampak yang terlihat adalah pergerakan IHSG yang sangat menurun. Pada tanggal 6 April 2020 dalam laman cnnindonesia.com menuliskan bahwa Sri Mulyani, Menteri Keuangan Repunlik Indonesia mengutarakan krisis yang disebabkan oleh virus corona sangat lebih kompleks jika dibandingkan dengan krisis 1997-1998 dan 20082009 .

Kementerian Keuangan mengatakan bahwa meningkatnya kasus Covid-19 secara drastis menimbulkan ancaman gangguan pada kesehatan, ancaman jiwa, serta ancaman pemasukan terutama warga yang kurang mampu dan keluarga yang bekerja di sektor informal. Selain itu, Covid-19 juga mengakibatkan macetnya kredit pada UMKM karena UMKM tidak dapat melaksanakan usahanya secara normal, sistem korporasi yang terdampak hingga kondisi perbankan yang dapat mengalami persoalan berupa likuiditas, depresiasi rupiah, volatilitas pasar keuangan serta capital flight (Mardiyah, Rahma Ainul., Nurwati, R. Nunung., 2020).

Covid-19 juga berdampak pada keadaan sosial dimana kurangnya interaksi sosial yang dilakukan antar masyarakat karena pembatasan sosial (Yanuarita et al., 2021). Salah satu 
dampak yang sangat signifikan adalah dampak sosial yang dialami oleh para penyintas Covid-19 laibat dianggap membawa penyakitanular (Dahono, 2020). Meskipun pemyintas telah dinyatakan sembuh, namun secara alami masih memiliki rasa takut menularkan kepada orng lain (Syarief, I.S., 2021). Stigma negatif para penyintas Covid-19 memunculkan fenomena penolakan terhadap jenazah penyintas Covid-19 di Depok. Keresahan ini muncul karena isu jenazah akan mengakibatkan pencemaran pada aliran sumber air warga sekitar (Saubani, 2020). Dalam hal ini seseorang yang penyintas Corona seringkali dianggap sebagai aib dalam lingkungan tersebut.

Stigma mengacu Kamus Besar Bahasa Indonesia didefinisikan sebagai ciri khas negatif yang pada diri seseorang dikarenakan pengaruh dari lingkungan sekitrnya. Ciri khas tersebut dapat iartikan sebagai tuduhan negatif yang diciptakan lingkungannya. Stigma masing-masing orang terhadap seseorang berbeda bergantung padasudut pandang yang mempengaruhi setiap orang (Jelahit, 2020). Stigma yang tinggi dari msyarakat akan menimbulkan kecemasan pada individu yang terstigma. Kecemasan merupakan perasaan tidak nyaman secara berlebihan yang merupakan suatu gejala psikologis atas rasa takut dari keadaan bahaya yang mengancam. Kecemasan muncul disertai dengan tangan bergemetar, jantung berdebar, serta berkeringat dingin. Jika terjadi secara terus menerus, hal ini akan berdampak terhadap kesehatan psikologis penyintas Covid-19 diantaranya trauma (Jelahit, 2020).

Trauma adalah sikap yang bisa dikatakan sebagai perubahan perilaku jangka panjang dari seseorang karena telah mengalami hal yang buruk. Seperti yang dikatakan oleh Soesilo (2014) mendefinisikan tentang arti kata trauma adalah sebuah peristiwa yang secara objetif dan memiliki interpretasi pribadi tentang maknanya sehingga dapat menimbulkan reaksi emosional dari orang tersebut. Respon yang ditunjukan dari rasa trauma biasanya adalah stress, penurunan rasa kontrol, dan merasa adanya ancaman dari sikap ego pada situasi tersebut.

Teori yang mendukung dalam penelitian ini adalah teori konstruksi realitas sosial. Teori ini berfokus pada tindakan manusia sebagai individu yang kreatif dari realitas sosialnya (Ritzer, 1985). Realitas sosial adalah hasil dari konstruksi yang diciptakan oleh masyarakat. Karena masyarakat selalu melakukan hubungan satu sama lain sehingga tidak hanya berperan sebagai korban namun juga pelaku dalam konstruksi sosialnya (Sulaiman, 2016). Realitas sosial terdiri dari tiga yaitu simbolik, objektif, dan subjektif. Realitas objektif tercipta dari pengalaman yang dilalui. Realitas simbolik mengekpresikan simbolik dari realitas objektif. Serta realitas subjektif berasal dari proses penyerapan kembali realitas simbolik dan objektif (Longhofer \& Winchester, 2016). Lewat teori ini, dapat dikaji hubungan antara pemikiran manusia dan konteks sosial tempat pemikiran itu timbul, berkembang dan dilembagakan (Jelahit, 2020).

Menurut Kamus Besar Bahasa Indonesia penyintas berasal dari kata sintas yang berarti individu yang terus bertahan hidup, mampu mempertahankan keberadaannya. Penyintas Covid-19 merupakan orang yang pernah mengalami terpapar virus corona atau pasien yang dinyatakan positif Covid-19 yang telah berhasil sembuh dari penyakitnya (Koesno, 2021). Sedangkan Covid-19 adalah penyakit menular yang diakibatkan oleh jenis coronavirus dan ditemukan di Wuhan, Tiongkok, pada bulan Desember 2019. 
Makna sebagai kecenderungan (diposisi) total untuk menggunakan atau bereaksi terhadap suatu bentuk bahasa (Sobur, 2003). Makna tersebut timbul dari suatu pengalaman. Pengalaman yang dimaksud dalam penelitian ini adalah pengalaman atas fenomena komunikasi pada penyintas Covid-19.

Penelitian yang relevan dengan kajian ini telah dilakukan oleh Novita dan Elon (2021) yang menunjukkan bahwa stigma instrumental dan simbolis masyarakat terhadap Covid-19 tergolong tinggi, sedangkan stigma kesopanan masyarakat cenderung rendah. Semakin tinggi stigma instrumental (pengetahuan) dan stigma simbolis (sikap) di masyarakat maka semakin buruk penerimaan masyarakat terhadap Covid-19. Munculnya stigma tersebut dalan masyarakat penyintas Covid-19 merasa rendah diri dan takut dipandang sebelah mata. Penyintas memutuskan untuk tidak mengikuti prosedur kesehatan bagi padien terkonfirmasi positif seperti melakukan isolasi. Penyintas bersikap seolah-olah tidak terpapar Covid-19 dan tetap bergaul di masyarakat sehingga akan memperbesar kasus (Novita \& Elon, 2021).

Lebih lanjut penelitian yang relevan selanjutnya dilakukan oleh Liu (2020) pada penduduk AS perilaku diskriminasi terkait Covid-19 meningkat dari $4 \%$ menjadi $10 \%$. Hal tersebut merupakan stigma masyarakat terhadap penyintas Covid-19. Persepsi diskriminasi terkait COVID-19 relatif rendah tetapi meningkat seiring waktu. Diskriminasi yang dirasakan dikaitkan dengan ras / etnis dan penggunaan masker wajah sehingga dapat menyebabkan tekanan mental yang besar selama tahap awal pandemi. Diskriminasi meningkat pada orang Asia dengan rasio 0.11 hingga 0.17. (Liu, Finch, Brenneke, Thomas, \& Le, 2020). Sedangkan pandangan penyintas Covid-19 akan penyakit itu sendiri atau disebut makna diri juga perlu untuk diungkapkan agar lingkungan mudah memberikan dukungan terhadap penyintas Covid-19. Maka dari itu dalam penelitian ini peneliti akan melakukan penelitian kualitatatif tentang makna diri penyintas Covid-19 khususnya di daerah Jakarta.

Alasan makna diri sebagai objek penelitian adalah karena penting untuk mengetahui bagaimana seorang penyintas covid memaknai dirinya setelah mengalami gejolak luar biasa. Makna diri yang dimaksud adalah kecenderungan individu untuk berseaksi terhadap suatu bahasa. Dalam komunikasi, makna diri diartikan sebagai pemahaman seorang individu yang mencangkup banyak pemahaman terhadap individu lain (Sulaeman., Mulyana, Deddy., 2019). Sehingga individu yang berbeda mungkin memiliki makna diri yang berbeda dengan individu lainnya.

Permasalahan tentang makna diri menjadi hal yang menarik ketika seseorang memiliki keterkaitan dengan interaksi sosial yang ada saat ini. Banyak hal yang mungkin berubah dan bisa saja tidak berubah. Salah satu contoh yang berkaitan dengan perubahan interaksi sosial yang terjadi saat ini disebutkan dalam kajian oleh Harahap (2020). Harahap (2020) menunjukkan bahwa terjadinya peningkatan kasus Covid-19 di Indonesia khususnya Kota Jakarta yang mengalami peningkatan kasus terbanyak berdampak pada pergeseran pola hidup. Pergeseran pola hidup menyebabkan munculnya perbedaan tingkatan individu sehingga menimbulkan keompokkelompok baru dalam masyarakat (Harahap, Siti Rahmah., 2020).

Maka dari pernyataan diatas dilakukanlah penelitian yang bertujuan untuk mengetahui bagaimana makna diri dari seseorang penyintas Covid-19 di Kota Jakarta. Urgensi dari penelitian ini adalah stigma negatif yang dialami oleh seorang penyintas Covid-19 yang menimbulkan 
dampak yang besar terhadap pola komunikasi yang akan terbangun dalam masyarakat. Interaksi yang dilakukan oleh penyintas Covid-19 dengan lingkungannya berbeda-beda jika dilihat melalui makna diri yang dialami penyintas Covid-19 tersebut. Kota Jakarta dipilih sebagai subjek penelitian karena kota Jakarta merupakan kota yang memiliki kasus Covid-19 tertinggi di Indonesia, melalui hal tersebut kota Jakarta dapat dikatakan sebagai kota yang terdampak paling besar akibat adanya Covid-19 ini.

\section{METODOLOGI}

Penelitian ini merupakan jenis penelitian kualitatif dengan metode fenomenologi. Penelitian kualitatif digunakan untuk mengetahui peritiwa yang telah atau sedang terjadi pada informan (Mulyana, D., 2011). Hal yang diteliti meliputi perilaku, tanggapan, motivasi, perbuatan dan yang lainnya dengan cara mendeskripsikan dalam wujud perkata dan juga bahasa, dalam suatu kondisi tertentu yang alamiah serta dengan menggunakan beberapa metode ilmiah. Dalam penelitian ini subjek penelitian yang dipilih adalah penyintas Covid-19 di Kota Jakarta.

Fenomenologi digunakan karena metode ini dapat menggali pengalaman dan makna terhadap suatu peristiwa kepada individu. Metode fenomenologi merupakan metode yang menganggao tindakan sosial menjadi sebuah teori (Sulaeman et al., 2019). Teori yang pada penelitian ini membutuhkan pengalaman dan makna yang diperoleh dari masingmasing individu. Sehingga masyarakat yang telah melalui peristiwa tertentu memiliki persepsi masing-masing meskipun mengalami peristiwa yang sama. Persepsi dari peristiwa yang mereka alami diinternalidasikan dari proses sosialisasi dan berpengaruh terhadap interaksi dan komunikasi (Apriliani \& Irina, 2021).
Peneliti menggunakan teknik pengumpulan data melalui wawancara (depth interview), observasi/pengamatan, studi literature serta dokumentasi. Teknik wawancara dipilih karena merupakan cara yang luwes untuk pengumpulan data, sehingga pertanyaan-pertanyaan yang diajukan terhadap informan bisa dijawab secara langsung sehinga dapat memperkuat data. Teknik observasi digunakan untuk melakukan pengumpulan data dengan mengadakan peninjauan secara langsung di lokasi penelitian yaitu di Kota Jakarta. Peneliti mengumpulkan berbagai data melalui literatur, jurnal, internet, dan buku cetak maupun non-cetak yang relevan dengan topik penelitian. Peneliti mengumpulkan segala dokumen-dokumen terkait dengan data yang akan diteliti seperti tulisan, gambar ataupun karya-karya monumental yang berasal dari seseorang.

Setelah hasil didapatkan, peneliti akan mendeskripsikan dan menggambarkan hasil penelitian tersebut melalui indepth interview kepada informan. Adapun penentuan informan yang dipilih oleh peneliti adalah menggunakan teknik Porposive Sampling. Proposive Sampling ialah salah satu dari sampling non random sampling. Teknik Porposive Sampling digunakan untuk mnentukan karakteristik tertentu yang relevan dengan tujuan penelitian dan diharapkan permasalahan yang diteliti dapat terjawab. Kriteria yang ditentukan oleh peneliti diantaranya adalah Penyintas Covid-19 pada awal mula kasus Covid-19 muncul di Indonesia, informan yang terlibat berada pada usia produktif yaitu 17-40 tahun serta berlokasi di Jakarta (Apriliani \& Irina, 2021).

\section{HASIL DAN PEMBAHASAN}

Seluruh informan yang terlibat dalam penelitian ini merupakan para penyintas Covid-19 di Jakarta. Para penyintas tentunya memiliki pemaknaan 
tersendiri terhadap dirinya sebagai para penyintas Covid-19. Melalui pengalaman yang diberikan oleh para informan muncul pertanyaan yang merujuk pada bagaimana makna diri penyintas Covid-19 di Jakarta.

Setiap individu akan mempunyai pengetahuan dan pemahaman mereka sendiri. Pengalaman yang pernah dialami akan membentuk suatu makna, dikarenakan pengalaman setiap individu pasti berbeda, maka setiap individu akan memiliki makna yang berbeda pula untuk kata-kata tertentu. Inilah yang kita sebut dengan makna perorangan, tetapi apabila setiap makna itu memiliki sifat perorangan, tentu tidak terjadi komunikasi dengan orang lain (Indriyani et al., 2020).

Dalam penelitian ini kelima informan mempunyai perbedaan dalam memaknai dirinya. Data yang diambil dalam penelitian ini adalah dengan menggunakan in depth interview yang dilakukan kepada 5 orang penyintas Covid-19 (tabel 1).

Tabel.1. Identifikasi Subjek Penelitian

\begin{tabular}{|c|c|c|c|}
\hline $\begin{array}{l}\text { Infor } \\
\text { man }\end{array}$ & $\begin{array}{l}\text { Jenis } \\
\text { Kelamin }\end{array}$ & Usia & Pekerjaan \\
\hline HR & Laki-laki & 55 & $\begin{array}{l}\text { Tidak } \\
\text { Bekerja }\end{array}$ \\
\hline NT & Perempuan & 29 & $\begin{array}{l}\text { Ibu Rumah } \\
\text { Tangga }\end{array}$ \\
\hline $\mathrm{M}$ & Laki-laki & 22 & $\begin{array}{l}\text { Karyawan } \\
\text { Swasta }\end{array}$ \\
\hline $\mathrm{F}$ & Laki-laki & 21 & Mahasiswa \\
\hline $\mathrm{NH}$ & Perempuan & 23 & Mahasiswa \\
\hline
\end{tabular}

Kelima informan diatas, sudah memenuhi kriteria yang telah diberikan oleh peneliti. Sebelum melakukan wawancara, informan telah melalui observasi terlebih dahulu. Informan yang terlibat telah dipastikan berasal dan tinggal di Kota Jakarta serta telah terinveksi Covid-19.

\section{Makna Diri Penyintas Covid-19 Di Jakarta}

Melalui data kelima informan dengan latar belakang yang berbeda, terdapat beberapa temuan atau hasil dari makna diri yang melibatkan kelima penyintas Covid-19. Kelimanya memberikan sikap yang berbeda-beda sesuai dengan pengalaman dan lingkungan masyarakat yang dialami oleh masing-masing penderita. Ada 5 sikap makna diri yang timbul dari informan penyintas Covid-19 antara lain :

\section{Makna Sikap Tertutup bagi Penyintas Covid-19}

Salah satu makna yang terbentuk dari para penyintas Covid-19 adalah penyintas memiliki kecenderungan untuk menghindari berinteraksi pada lingkungan, pendapat ini diungkapkan oleh HR, NT, dan NH, mengungkapkan bahwa menghindari berkomunikasi dengan lingkungan sekitarnya. Berpikiran negatif dan menganggap orang lain akan mengucilkan, menggosipkan, menjauhinya atau memberikan stigma kepadanya ketika berinteraksi. Seperti informan HR saat diwawancara ia mengungkapkan :

"Saya dan keluarga lebih tertutup
mengenai apa yang sedang saya
alami, karena pada saat itu Covid
ini sangat horor dan kami memilih
untuk menutupinya karena takut
ada omongan yang gaenak dari
tetangga ke keluarga saya"

Stigma negatif dari masyarakat akan memberikan dampak yang berbeda kepada setiap orang. Salah satunya yang dialami oleh HR yang menjelaskan bahwa kehidupan lingkungan sangat berpengaruh terhadap interaksi yang akan dipilih oleh seseorang. Seperti yang dikatakan oleh Harahap (2020) menjelaskan bahwa sikap dari lingkungan sangat mempengaruhi 
interaksi sosial dari masing-masing individu. Dalam hal ini banyak kekhawatiran dan aturan baru di masyarakat dapat menimbulkan strata dan kelompok sosial yang baru. Interaksi sosial yang diakibatkan juga dapat memutuskan untuk menjauhi kehidupan sosial masyarakat secara normal dan lebih menutup diri.

Sama halnya yang dikatakan Abdillah Livana (2020) bahwa masyarakat yang terjangkit Covid-19 mendaoatkan stigma negatif dari masyarakat. Stigma negatif berupa pengucilan akan membuat penyintas merasa rendah diri dan menutup diri dari masyarakat bahkan tidak sedikit yang menyembunyikan karena menganggab sebagai aib. Livana (2020) memaparkam bahwa pengucilan tidak hanya terjadi pada pasien melainkan pada pasien yang telah sembuh, orang yang telah melalui perjalanan jauh, etnis yng dianggap membawa virus, tenaga medis yang menangani Covid-19 serta jenazah yang hendak dimakamkan.

Pembentukan makna diri dari seseorang, seperti yang dijelaskan dalam pernyataan diatas adalah sebuah makna yang dihasilkan melalui konstruksi realitas dari masyarakat dan lingkungan. Melalui anggapan diatas, seolah menyetujui tentang makna diri baru yang ditimbulkan dari adanya pandemi Covid-19 yaitu penyintas memilih untuk menjauh berinteraksi dengan sosial karena adanya aturan dan norma baru serta stigma negatif yang dialami oleh informan. Ketakutan yang dialami oleh para informan juga diakibatkan oleh pemberitaan dari media. Seperti yang dikatakan oleh informan HR dan keluarga lebih memilih untuk tertutup karena sebelumnnya ia membaca dan menonton kabar-kabar mengenai banyak orang yang terkena stigma yang diakibatkan oleh Covid-19. Informan HR juga saat dinyatakan sudah sembuh dan HR berkomunikasi dengan lingkungan, cenderung menutup diri. Tepat seperti pemaparan Livana (2020) bahwa dampak sosial dari stigma negatif masyarakat dapat mendorong individu untuk menyembunyikan penyakit untuk menghindari diskriminasi.

Kondisi ini sangat berpengaruh kepada mereka saat melakukan interaksi hingga mengalami hambatan komunikasi karena selalu beranggapan negatif kepada orang lain. Salah satu penyebab dari ketakutan penyintas terhadap virus Covid19 ini juga disebabkan oleh pemberitaan dari media massa yang cenderung menakut-nakuti tentang bahayanya virus tersebut. Seperti yang dikatakan oleh Triyaningsih (2020) bahwa media massa dapat memberikan asumsi yang berbeda dengan kenyataan. Seseorang yang memiliki karakteristik yang berbeda akan terpengaruh dengan cara yang berbeda pula oleh media massa. Dengan kata lain, media massa memiliki dampak yang cukup besar terhadap cara seseorang berperilaku.

Pemberitaan media tentang penyakit Covid-19 juga akan mempengaruhi kesehatan mental penyintas Covid-19. Seperti yang dikatakan oleh Vibriyanti (2020) bahwa pemberitaan dari media yang selalu mendadak dan hampir setiap hari serta terus-menerus mengenai Covid19 akan menimbulkan sikap cemas dalam pemikiran seseorang. Adanya informasi serta kebijakan yang dibangun terkait Covid-19 akan mempengaruhi penilaian dari seseorang dan menimbulkan respon dari seseorang dan lingkungan yaitu dengan kecemasan yang berlebih dan berimbas pada tindakan pengucilan.

Hal diatas menjadi salah satu alasan informan untuk merubah makna diri dari interaksisosial yaitu dengan menutup diri dari masyarakat karena memiliki kekhawatiran akan mendapatkan stigma yang negatif.

Tingkatan konstruksi makna yang diberikan oleh informan diatas dapat digambarkan dala tabel berikut ini : 


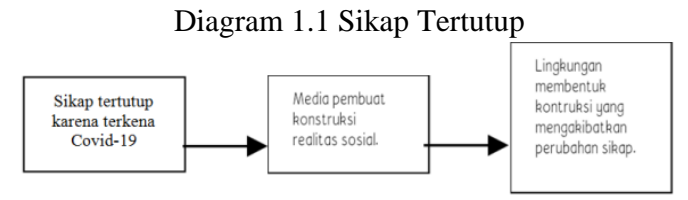

Sumber: data hasil penelitian, Februari 2021

Pada tahapan pertama, makna dari kata "tertutup" yang dialami oleh penderita Covid-19 memiliki banyak persoalan yang terdapat di dalamnya. Pertama adalah adanya stigma negatif tentang penyakit Covid-19 yang masih dipegang oleh masyarakat Indonesia. Anggapan tersebut diungkapkan oleh informan bahwa dikarenakan penyakit Covid-19 adalah penyakit yang mudah menular sehingga dianggap sebagai aib bagi diri seniri maupun keluarga. Seperti yang dikatakan oleh Abudi et al., (2020) bahwa stigma negatif yang seringkali didapatkan oleh penderita Covid-19 dan juga keluarga yang tinggal bersamanya adalah penyakit menular yang dapat menjadi sebuah aib dan akan dijauhi oleh lingkungan sekitarnya karena proses penularan penyakit Covid-19 sangatlah cepat dan dapat berakibat pada kematian. Selain itu stigma negatif juga dilakukan oleh masyarakat dengan alasan penyakit Covid-19 belum memiliki obat yang dapat menyembuhkan sehingga akan berdampak sangat besar terhadap kesehatan.

Konstruksi yang diberikan mengenai representasi dari sebuah "penyakit" adalah hal yang seringkali diperdebatkan oleh masyarakat. Mendengar kata "penyakit menular" saja, hal tersebut telah menjadi perdebatan yang tak kunjung padam. Dilema tentang adanya penyakit Covid-19 dan makna yang terkandung didalam kata penyakit tersebut memberikan perubahan sikap dan budaya yang ada dalam masyarakat. Dengan adanya sikap tertutup, menjadikan perubahan budaya yang cukup signifikan yang dialami oleh masyarakat Indonesia yang dikenal sangat erat dengan kehidupan sosial. Anggapan tersebut juga dikatakan oleh Kuntardi (2021) bahwa masyarakat Indonesia dahulunya dikenal sebagai masyarakat yang memiliki tingkat interaksi dan solidaritas sosial yang cukup tinggi. Hal tersebut ditunjukan melalui kontrol sosial yang cukup ketat dan tradisi lokal masyarakat yang cukup kuat. Seperti contohnya tradisi keagamaan, tradisi gotong royong, dan hal yang lainnya. Masyarakat Indonesia sering mengadakan kegiatan untuk menjalin hubungan komunikasi dan selalu membutuhkan orang lain. Namun adanya pandemi Covid-19 perilaku sosial budaya masyarakat di Indonesia berubah 180 derajat.

Perubahan budaya tersebut merupakan dampak dari konstruksi lingkungan akibat Covid-19, karena pembentukan budaya sangat dipengaruhi oleh kehidupan sosial yang terjadi dilingkungan tersebut. Peran lingkungan dalam membentuk sebuah makna diri yang ditampilkan dari perilaku sosial dapat dirasakan dalam lingkungan tersebut. Salah satu contohnya adalah yang dijelaskan oleh informan HR diatas. Dirinya menyatakan bahwa dahulunya sebelum terkena Covid-19, komunikasi yang dilakukan bersama dengan masyarakat sangatlah erat. Namun memudar seiring stigma negatif yang beredar dimasyarakat membuat informan menarik diri dari berinteraksi dengan lingkungan sekitar.

Namun, makna yang dilakukan dengan cara "sikap tertutup" juga dipengaruhi dari pandangan atau persepsi masyarakat sekitar tentang apa yang dialami. Masyarakat dan budaya masyarakat memiliki keterkaitan yang sangat besar dalam mempersepsikan penyintas Covid-19. Dalam hal ini seperti dialami oleh informan bahwa masih banyaknya masyarakat Jakarta yang memandang sebelah mata penderita Covid-19. Pernyataan informan didukung 
oleh Dai (2020) bahwa lingkungan sosial sangat berpengaruh terhadap kehidupan masyarakat untuk dapat bertahan dalam situasi pandemi. Namun kenyataannya faktor lingkungan sosial justru masih menjadi faktor kegagalan masyarakat membangun suasana positif pada penyintas Covid-19.

Banyak bukti yang jelas seringkali dilakukan oleh penyintas Covid-19 yaitu dengan menutupi atau defensif untuk menyembunyikan penyakitnya dan lebih memilih untuk tidak mengobati penyakit tersebut dengan cara yang lebih tepat. Stigma dan rasa takut yang dialami oleh penderita Covid-19 menghambat respon dan justru akan memperumit masalah tentang kasus penyakit yang menular tersebut (Dai et al., 2020).

Makna tertutup yang ketiga adalah terdapat pemahaman yang cukup mendalam tentang konstruksi budaya masyarakat dan sikap yang akan diambil oleh masyarakat sebagian besar ditentukan oleh apa yang ditampilkan dalam media. Seperti yang telah dijelaskan sebelumnya bahwa media memiliki pengaruh yang cukup besar dalam konstruksi budaya masyarakat. Namun, di Indonesi media justru menimbulkan keresahan dalam masyarakat.

Menurut Dai (2020) bahwa media massa merupakan sarana yang berperan penting dalam mengurangi stigma sosial masyarakat. Dalam hal ini media harus mengurangi pemberitaan yang menimbulkan rasa kecemasan yang berlebih serta memprovokasi hal-hal yang dapat berdampak negatif bagi masyarakat. Media seharusnya dijadikan sebagai sarana edukasi dan informasi yang membuat masyarakat tidak hanya mengerti informasi tentang Covid-19 tetapi juga berpikiran positif. Informan mengatakan bahwa sikap tertutup seseorang memiliki keterkaitan dengan kesadaran masyarakat tentang peran media itu sendiri. Media seringkali menambahkan atau mengurangi berita yang ditampilkan dengan tujuan untuk menambah empati dari masyarakat untuk kepentingan tertentu.

Seperti yang dikatakan oleh Ayun (2015) mengatakan bahwa media menjadi penyebab yang paling utama dari perubahan budaya dan pembentukan mana diri dari seseorang. Media dapat dikatakan sebagai sebuah sarana untuk memperpanjang atau sebuah eksistensi dari pemikiran manusia dan dapat mempengaruhi perkembangan pemikiran manusian.

Media dapat menjadi sebuah sarana untuk membentuk sebuah sikap yang akan dilakukan oleh masyarakat. Melalui sikap tertutup, para penyintas Covid-19 akan lebih merasa aman dan nyaman karena tidak membarikan dampak secara mental terhadap penyintas Covid-19. Dengan adanya stigma negatif yang diberikan oleh lingkungan masyarakat, makna dari sikap tertutup yang dipilih oleh penderita Covid-19 memberikan rasa aman.

\section{Makna Sikap Ketakutan bagi Penyintas Covid-19.}

Makna diri yang ditunjukan oleh informan adalah sikap ketakutan. Dalam hal ini, rasa takut dirasakan hampir oleh seluruh informan yang diwawancara. Mereka takut menularkan virusnya kepada orang terdekat terutama orang yang terakhir kontak. Seperti yang dikatakan oleh informan NT dibawah ini :

\footnotetext{
"Aku tuh takut banget pas tau aku positif, karena waktu itu aku habis ketemu ayah aku dan dia bekerja di Bekasi, aku mikirnya udah kemana-mana kalo dia kena siapa yang ngurusin dan ayah aku udah tua umurnya"
} 
Informan NT juga menceritakan ketakutannya karena saat dia melakukan isolasi di rumahnya, NT harus menjaga adik-adiknya dikarenakan orangtuanya pun sedang melakukan isolasi di Rumah Sakit. Ketakutannya semakin menjadi, disaat ia berjuang untuk sembuh tetapi harus menjaga adik-adiknya juga, NT takut adik-adiknya tertular virusnya.

Rasa takut menjadi hal yang wajar bagi setiap orang yang sedang mengalami hal yang buruk. Namun sebagian besar penyintas Covid-19 memiliki ketakutan yang lebih karena bukan hanya takut menerima stigma negatif bagi masyarakat, kadangkala juga memiliki rasa takut kehilangan orang terdekat atau keluarganya. Hal tersebut juga dapat menjadi salah satu perubahan mental dan penyintas Covid-19. Seperti yang dikatakan oleh Ilpaj dan Nurwati Ilpaj et al., (2020) yang menjelaskan bahwa sikap takut dan cemas yang berlebihan terhadap diri sendiri dan orang terdekat seringkali dialami oleh seseorang yang mengidap Covid-19. Namun dalam hal ini seseorang merasakan ketakutan juga dapat diakibatkan oleh ada ancaman oleh suatu hal yang mungkin saja tidak jelas keberanannya. Rasa takut tersebut juga mempengaruhi interaksi seseorang dengan lingkungan sekitarnya.

Menurut Ilpaj dan Nurwati (2020) penderita Covid-19 akan merasakan ketakutan dan kecemasan yang berlebih karena takut kehilangan orang yang disayanginya. Anggapan di atas menunjukan bahwa rasa takut yang dimiliki oleh penyintas Covid-19 juga mempengaruhi kesehatan mental dan makna diri dari seseorang. Rasa takut tersebut dapat disebabkan oleh ancaman dari lingkungan masyarakat sekitarnya.

Ketakutan yang dialami oleh penyintas Covid-19 menimbulkan rasa tidak percaya terhadap lingkungan yang ada disekitarnya. Dalam hal ini dapat digambarkan melalui diagram 1.2 :

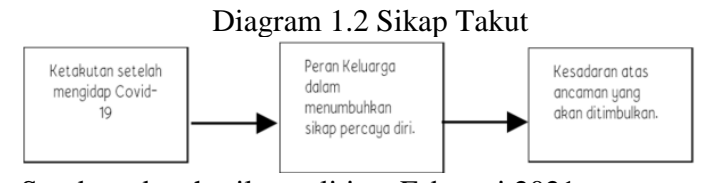

Sumber: data hasil penelitian, Februari 2021

Dalam hal ini informan memiliki konstruksi yang cukup berbeda karea mengidap penyakit Covid-19. Makna dari sikap penuh rasa takut seringkali dirasakan oleh para penyintas Covid-19 bukan hanya khawatir akan dirinya melainkan juga keluarga. Rasa takut yang dimiliki tidak hanya semata-mata karena bahayanya penyakit Covid-19 bagi kesehatan. Namun juga ancaman lingkungan sekitar terhadap keluarga.

Seperti yang dikatakan oleh Vibriyanti (2020) bahwa rasa takut dan cemas dari penderita Covid-19 seringkali berasal dari adanya persepsi terhadap sebuah peristiwa yang tidak dapat dikendalikan, seperti banyaknya pengucilan yang dilakukan oleh tetangga, dikurung didalam rumah dan tidak boleh bertemu dan berinteraksi sama sekali secara langsung dengan orang lain, serta pemahaman yang keliru tentang penyakit Covid-19. Sehingga indovidu akan lebih fokus terhadap tindakan yang lebih aman dan nyaman. Namun, dalam hal ini, makna dari sikap ketakutan yang dialami oleh para penyintas adalah justru tentang adanya kesadaran akan ancaman yang ditimbulkan dari penyakit tersebut.

Seperti yang dikatakan oleh Vibriyanti (2020), salah satu dampak pandemi Covid-19 adalah trauma, bingung, gelisah yang berlebihan, ketakutan akan adanya ancaman yang akan terjadi. Banyak yang mengalami ganggu mental baik bagi penyintas Covid19 dan juga keluarga yang ada disekitar penyintas tersebut. Ketakutkan yang berlebihan dapat mengakibatkan gangguan mental yang lebih berat. 
Makna rasa penyesalan dan
kebingungan bagi Penyintas Covid-19.

Pengalaman dan makna diri yang dialami oleh informan selanjutnya adalah adanya rasa penyesalan. Rasa penyesalan dirasakan oleh informan $M$. Informan $M$ menganggap bahwa dirinya terkena penyakit Covid-19 karena dirinya lalai ketika berkumpul bersama temantemannya. Kebiasaan yang dilakukan oleh anak muda saat ini adalah budaya "nongkrong" yang memang masih susah dijauhkan dari kehidupan anak muda saat ini. Hal tersebut yang kemudian menjadi rasa penyesalan yang timbul dari diri informan ketika dirinya mengidap Covid19. Seperti yang dikatakan oleh informan M dibawah ini :

\section{"Gua nyesel sih sampai sekarang kalo inget itu, dulu gua anaknya tongkrongan banget. Dan saat gua terkena, gua juga nularin ke bokap gua"}

Informan $\mathrm{M}$ menceritakan bahwa dirinya sangat menyesal sering mengabaikan protokol kesehatan, sering berkumpul bersama teman-temannya. M menceritakan bahwa ayahnya yang terjangkut Covid-19 keungkinan besar tertular olehnya sehingga tidak daoat tertolong karena mmiliki penyakut bawaan yang serius. Rasa penyesalan tersebut juga dituliskan oleh Ilpaj dan Nurwati (2020) bahwa perasaan bersalah menjadi salah satu hal yang banyak dialami oleh penderita Covid-19. Hal tersebut seringkali menjadi pergulatan batin penyaintas dengan dirinya sendiri. Berdasarkan pengalaman informan $\mathrm{M}$ maka rasa bersalah dapat menimbulkan perubahan interaksi penyintas terhadap lingkungannya. Rasa bersalah dapat menyebabkan kecemasan yang berlebihan bagi penyintas Covid-19.

Selain rasa penyesalan, informan
juga mengalami rasa bingung.

Kebingungan dirasakan oleh informan yang berinisial $\mathrm{F}$, adalah kesalahan persepsi mengenai gejala penyakit Covid29 yang diasumsikn sebagai sinus. Dikarenakan informan memikiki riwayt penyakit sinus. Namun setelah dilakukan pemeriksaan gejala tersebut merupakan Covid-19. Gejala yang dialami F adalah demam, batuk, tidak bisa mencium dan merasakan indra perasa. F mengatakan :

$$
\begin{aligned}
& \text { "Saya bingung karna waktu } \\
& \text { saya ke puskesmas, yang jaga } \\
& \text { disana malah ketakutan sama } \\
& \text { saya." }
\end{aligned}
$$

Informan $\mathrm{F}$ memaparkan setelah dilakukan pemeriksaan tenaga kesehatan yang menanganinya menunjukkan sikap preventif yang berlebihan sehingga menimbulkan ketakutan yang berlebihan. Namun tidak ada arahan lebih lanjut dari tenaga kesehatan. Dalam hal ini, terlihat bahwa rasa bingung yang dialami oleh penyintas Covid-19 dikarenakan penanganan dan bahasa non verbal yang diberikan oleh tenaga medis terhadap penyintas Covid-19. Hal itu menunjukkan pentingnya sikap tenabga kesehatan dalam memberikan informasi dan ketenangan sehingga penyintas dan orang lain tidak mengalami kebingungan dan ketakutan. Setelah melakukan pemeriksaan gejala, informan $\mathrm{F}$ kemudian melakukan tes PCR.

Pengalaman yang dialami oleh informan $\mathrm{F}$ menunjukan adanya makna diri yang disebabkan oleh penerimaan dan sikap bahasa non verbal atau gesture yang diberikan oleh lingkungan sekitarnya terhadap dirinya. Melalui hal tersebut gesture atau bahasa non verbal mempengaruhi sikap interaksi sosial yang ada. Seperti yang dikatakan oleh Gani et al., (2020) mengatakan bahwa di era Covid-19 saat ini, bahasa non verbal sangat mempengaruhi sikap yang diterima seseorang. Dengan kata lain, pada era 
sebelumnya, seseorang mungkin lebih memiliki pemikiran positif karena dapat melihat bahasa non verbal dengan senyuman. Namun saat ini, bahasa non verbal yang seolah menjauhi penderita Covid-19 akan menyebabkan interaksi yang berbeda pula.

Anggapan diatas, menjelaskan bahwa rasa bingung yang dialami oleh penyintas Covid-19 juga dapat dipengaruhi oleh bahasa non verbal yang dari orang lain karena kebijakan pemerintah untuk menaati protokol kesehatan menggunakan masker. Di era saat ini banyak orang memiliki kesalah pahaman terhadap sikap atau interaksi seseorang yang memiliki gejala penyintas Covid-19.

Peristiwa informan diatas menunjukkan rasa penyesalan dan kebingungan yang dialami oleh penyintas Covid-19 memiliki makna yang cukup mendalam yaitu adanya pergeseran tingkah laku dan gaya hidup yang akan terjadi ketika seseorang pernah mengidap Covid-19. Seperti yang digambarkan pada diagram 1.3.

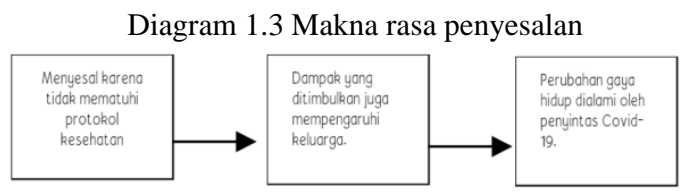

Sumber: data hasil penelitian, Februari 2021

Pada diagram diatas menunjukan adanya makna yang berkembang melalui makna rasa penyesalan yang dirasakan oleh penyintas Covid-19. Dalam hal ini, para para penyintas Covid-19 memaknai terpaparnya mereka dikarenakan kelalaian pribadi karena tidak mematuhi protokol kesehatan. Namun jika ditelisik lebih mendalam, rasa penyesalan berkembang menjadi akibat yang ditinbulkan setelah dirinya terpapar. Yaitu menularkna pada orang lain terutama keluarga.

Seperti yang dikatakan oleh Dani (2020) menjelaskan tentang dampak dari peyakit Covid-19 terbesar adalah menularkan kepada keluarga terdekat terutama yang melakukan kontak fisik dengannya. Jika ditarik lebih mendalam lagi, makna dari rasa penyesalan mengakibatkan perubahan perilaku seseorang yang akan dapat menularkan kepadaorang lain. Seperti pemaparan informan diatas bahwa penyesalan mengubah gaya hidup informan yang tidak mematuhi protokol kesehatan menjadi lebih memperhatikan protokol kesehatan.

Rasa bingung yang dialami oleh penyintas Covid-19 adalah sebuah hal yang wajar. Dapat dilihat melalui beberapa pemikiran yang dimaknai oleh informan diatas, karena penyakit Covid19 tergolong pada penyakit yang baru sehingga kurangnya informasi dan kecemasan yang berlebihan akan menimbulkan kebingungan. Hal itu memberikan dampak bagi penyintas terhadap orang yang ada disekitarnya.

Banyak hal yang kemudian berubah dengan banyaknya penyintas Covid-19 salah satunya adalah perubahan gaya hidup masyarakat yang saat ini mengurangi untuk makan di tempat yang ramai, mendatangi mall dengan situasi yang ramai dan banyak yang lain. Hal tersebut juga dapat dikatakan sebagai dampak dari rasa penyesalan penyintas Covid-19. Menurut Utama (2020) menjelaskan tentang perubahan gaya hidup yang dialami oleh masyarakat pada saat pandemi sangat beragam seperti misalnya menjadi lebih menjaga kebersihan, selain itu tingkat belanja atau berkerumun untuk berkumpul bersama teman juga jadi lebih berkurang. Namun dalam hal negatif juga mengakibatkan pergerakan ekonomi semakin menurun.

\section{Makna "Trauma" Penyintas Covid-19}

Pengalaman dan perasaan yang dialami oleh penyintas Covid-19 di Jakarta adalah trauma. Rasa trauma dirasakan oleh informan $\mathrm{HR}, \mathrm{M}$, dan $\mathrm{NH}$. 
Mereka takut berpergian ke tempat ramai, walaupun telah dinyatakan sembuh, seperti yang diceritakan oleh informan $\mathrm{NH}$

"Sekarang aja aku ga berani ke
pasar atau main ke tempat-
tempat rame, kayanya aku
masih trauma sampe
sekarang."

Dengan adanya peristiwa tersebut NH menjadi lebih protektif terhadap dirinya sendiri terutama saat pulang dari keramaian. $\mathrm{NH}$ lebih peduli dengan kesehatan dan kebersihannnya, dengan giat berolahraga, berjemur dan minum vitamin agar memperkuat imun tubuh. $\mathrm{NH}$ mengalami ketalutan yang berlebihan saat timbul gejala seperti batuk dan demam. Rasa trauma yang dialami oleh beberapa informan bisa jadi dikarenakan ketakutan yang berlebihan yang dialami. Hal tersebut menimbulkan interaksi sosial yang baru yaitu perubahan pola berinteraksi dengan kehidupan sosialnya. Para penyitas Covid-19 , akan lebih menutup diri dan lebih memilih untuk tidak melakukan interaksi sosial dengan banyak orang. Hal tersebut sebenarnya, berkontradiksi terhadap sifat alami manusia yaitu sebagai makhluk sosial. Seperti yang dikatakan oleh Gani, et al., (2020) menjelaskan bahwa manusia adalah makhluk sosial maka dari itu, manusia sangat membutuhkan interaksi dengan sekitarnya. Namun hal tersebut mungkin tidak dapat dirasakan dalam era Covid-19 saat ini. Sebagian besar manusia yang telah terpapar Covid-19 takut berinteraksi dengan banyak orang termasuk lingkungan sekitarnya. Akibatnya, interaksi sosial menjadi semakin terganggu dalam kehidupan bermasyarakat.

Trauma adalah sikap yang bisa dikatakan sebagai perubahan perilaku jangka panjang dari seseorang karena telah mengalami hal yang buruk. Seperti yang dikatakan oleh Soesilo (2014) mendefinisikan tentang arti kata trauma adalah sebuah peristiwa yang secara objetif dan memiliki interpretasi pribadi tentang maknanya sehingga dapat menimbulkan reaksi emosional dari orang tersebut. Respon yang ditunjukan dari rasa trauma biasanya adalah stress, penurunan rasa kontrol, dan merasa adanya ancaman dari sikap ego pada situasi tersebut.

Banyak jenis trauma yang diakibatkan dari penyakit Covid-19. Trauma yang dialami oleh penyintas Covid-19 bukan hanya dirasakan secara fisik dan organ tubuh saja, melainkan bisa secara mental atau psikis yang dialami oleh penyintas tersebut. Dalam hal ini, makna dari "trauma" yang dibawakan oleh penyintas Covid-19 adalah gabungan dair ketakutan dan rasa penyesalan yang mendalam yang berakibat pada perilaku dijangka panjang. Makna trauma yang dialami oleh seseorang yang pernah mengidap penyakit Covid-19 adalah halhal yang dapat menjadi pembelajaran kedepannya. Karena trauma dapat menimbulkan makna diri tentang kesadaran akan kewaspadaan gejala Covid-19 yang diderita oleh lingkungan sekitarnya.

Makna diri yang terkadung dalam perasaan trauma adalah sebuah kewaspadaan terhadap bahaya dan ciriciri dari gejala penyakit Covid-19. Hal tersebut memiliki dampak positif yaitu lebih meningkatkan kewaspadaan diri terhadap bahaya yang mengancam dalam hal ini adalah sebuah penyakit menular. Seperti yang dikatakan oleh Soesilo (2014) mengatakan bahwa trauma yang dimiliki oleh seseorang dapat memberikan sebuah sikap kewaspadaan yang tinggi terhadap suatu hal yang dipandang buruk atau tidak enak yang pernah dialami oleh dirinya.

Melalui hal tersebut makna diri dari rasa trauma yang dialami oleh penderita Covid-19 adalah sebuah 
kewaspadaan yang lebih dalam dan tajam terhadap suatu hal yang dianggap sebagai sebuah ancaman. Kewaspadaan tersebut kemudian menunjukan ketidakinginan seseorang untuk mengulang kejadian buruk yang sama yang akan terjadi terhadap dirinya dan orang disekitarnya. Itulah yang akan mempengaruhi kehidupan dalam masa mendatang seorang yang sedang atau pernah terpapar Covid-19.

\section{SIMPULAN}

Berdasarkan uraian hasil penelitian dan penyajian konsep serta teori dalam pembahasan, kesimpulan yang didapat oleh peneliti adalah bahwa makna diri penyintas Covid-19 di Jakarta dikategorisasikan menjadi lima, yaitu : a) Makna sikap tertutup bagi penyintas Covid-19; b) Makna sikap ketakutan bagi penyintas Covid-19 ; c) Makna rasa penyesalan dan kebingungan bagi penyintas Covid-19; d) Makna "trauma" penyintas Covid-19. Kelima makna ini terbentuk berdasarkan pengalaman komunikasi yang dihadapi penyintas di masa sekarang dan masa lalu sehingga terbentuklah sebuah konstruksi makna tersebut.

\section{DAFTAR PUSTAKA}

Abudi, R., Mokodompis, Y., \& Magulsili, A. (2020). Stigma Terhadap Orang Positif Covid-19. Jambura Journal, 2(2), 77-84.

Apriliani, R., \& Irina, D. (2021). Studi Fenomenologi Persepsi Masyarakat Dalam Penerapan Protokol Covid19. REAL in Nursing Journal (RNJ), 4(1), 44-499.

Ayun, P. (2015). Fenomena Remaja Menggunakan Media Sosial dalam Membentuk Identitas. Channel Journal, 3(2), 1-16.

Dahono, Y. (2020). Kisah Penyintas Covid-19, dari Dirundung hingga
Disebut Pembawa Virus. Berita Satu. https://www.beritasatu.com/kesehata n/639269/kisah-penyintas-covid19dari-dirundung-hingga-disebutpembawa-virus

Dai, N. F. (2020). Stigma Masyarakat Terhadap Pandemi Covid-19. Proseding Seminar Nasional, 1, 6673.

Dani, J. A., \& Mediantara, Y. (2020). Covid-19 dan Perubahan Komunikasi Sosial. Persepsi: Communication Journal, 3(1), 94102.

https://doi.org/10.30596/persepsi.v3i 1.4510

Jelahit, F. E. (2020). Peran Komunikasi Sebagai Mitigasi Stigmatisasi Covid 19. Jurnalisa, 6(1), 19-22.

Gani, N., Sidabutar, N., Sila, A., Yuliarti, A., Hermansyah, B., Umar, N., Wandi., Fathiyah., Fitriana, D., Fitriani., Thalib, F., Aslam, M., \& Sahid, M. (2020). Covid 19 Dalam Bingkai Komunikasi. IAIN Parepare Nusantara Press.

Harahap, S. R. (2020). Proses Interaksi Sosial Di Tengah Pandemi Virus Covid 19. AL-HIKMAH: Media Dakwah, Komunikasi, Sosial Dan Budaya, 11(1), 45-53. https://doi.org/10.32505/hikmah.v11 i1.1837

Hong, E. (2020). Virus corona 'kemungkinan berasal dari ular, dan belum ada vaksin. BBC. https://www.bbc.com/indonesia/maj alah-51231635

Ilpaj, S. M., \& Nurwati, N. (2020). Analisis Pengaruh Tingkat Kematian Akibat Covid-19. Jurnal Pekerjaan Sosial, 3(1), 16-28.

Indriyani, P., Yusuf, E., \& Ramdhani, M. (2020). Konstruksi Makna Perempuan Pergerakan. WACANA: Jurnal Ilmiah Ilmu Komunikasi, 19(2), 238-248. https://doi.org/10.32509/.v19i2.1105 
Koesno, D. (2021). Arti Penyintas COVID-19 dan Kisah Mereka Melawan Virus Corona. Tirto.Id. Diakses 9 Februari 2021 https://tirto.id/arti-penyintas-covid19-dan-kisah-mereka-melawanvirus-corona-f9z5

Kuntardi, D. (2021). Dinamika Sistem Sosial Masyarakat Pedesaan di Masa Pandemi Covid-19. Jurnal Ideas: Pendidikan, Sosial, Budaya, 7(1), 110.

Liu, Y., Finch, B. K., Brenneke, S. G., Thomas, K., \& Le, P. D. (2020). Perceived discrimination and Mental Distress amid the COVID-19 pandemic: Evidence from the understanding America study. American Journal of Preventive Medicine, 59(4), 481-492. https://doi.org/https://doi.org/https:// doi.org/10.1016/j.am epre.2020.06.007

Livana, P. H., Setiawati, L., \& Sariti, I. (2020). Stigma dan Perilaku Masyarakat pada Pasien Positif COVID-19. Jurnal Gawat Darurat, 2(2), 95-100.

Longhofer, W., \& Winchester, D. (Eds.). (2016). Social Theory Re-Wired: New Connections to Classical and Contemporary Perspectives (2nd ed.). Routledge. https://doi.org/10.4324/9781315775 357

Mardiyah, R. A., \& Nurwati, R. N. (2020). Dampak Pandemi Covid-19 Terhadap Peningkatan Angka Pengangguran di Indonesia. Jurnal Global Health Science Groupoup, 1(1), 1-20.

Mulyana, D. (2011). Metode Penelitian Kualitatif. Roda Karya.

Novita, S., \& Elon, Y. (2021). Stigma Masyarakat terhadap Penderita Covid-19. Jurnal Kesehatan, 12(1), 25-33.

https://doi.org/http://ejurnal.poltekke
s-tjk.ac.id/index.php/JK

Pemerintah DKI Jakarta. (2021). Data Pemantauan Covid-19. https://corona.jakarta.go.id/id/datapemantauan.

Ritzer, G. (1985). Konstruksi Sosial Peter L. Berger Dan Thomas Luckmann. Sosiologi Ilmu Pengetahuan Berparadigma Ganda.

Saubani, A. (2020). Jangan Tolak Pemakaman Jenazah Pasien Covid$19 . \quad$ Republika.Co.Id. https://republika.co.id/berita/q83zsk 409/jangan-tolak-pemakamanjenazah-pasien-covid19

Sobur, A. 2003. Psikologi Umum. Bandung : Pustaka Setia.

Soesilo, A. (2014). Trauma Experience, Identity, and Narratives. Buletin Psikologi Fakultas Psikologi Universitas Gadjah Mada, 22(1), 117.

Sukur, M. H., Kurniadi, B., \&Faradillah N. R. (2020). Penanganan Pelayanan Kesehatan Di Masa Pandemi Covid19 Dalam Perspektif Hukum Kesehatan. Journal Inicio Legis, 1(1), 1-17.

Sulaeman., \& Mulyana, D. (2019). Makna Diri Penyandang Oligodaktili. Jurnal Penelitian Komunikasi, 22(1), 3146.

https://doi.org/10.20422/jpk.v22i1.5 95

Sulaiman, A. (2016). Memahami Teori Konstruksi Sosial Peter L. Berger. Society, 4(1), 15-22. https://doi.org/10.33019/society.v4i 1.32

Syarief, I.S. (2021). Cara Memulihkan Psikis Penderita dan Penyintas Covid-19. Suara Surabaya. https://www.suarasurabaya.net/seng gang/2021/cara-memulihkan-psikispenderita-dan-penyintas-covid-19/.

Triyaningsih, H. (2020). Efek Pemberitaan Media Massa Terhadap Persepsi Masyarakat Pamekasan 
tentang Virus Corona. Meyarsa, 1(1), $1-21$.

Utama, L. (2020). Gaya Hidup Mayarakat Nusa Tenggara Timur Dalam Menghadapi Pandemi Corona Virus Disease 19 (Covid-19). An-Nadaa: Jurnal Kesehatan Masyarakat, 7(1), 34-40.

Vibriyanti, D. (2020). Kesehatan Mental Masyarakat: Mengelola Kecemasan di Tengah Pandemi Covid-19. Jurnal
Kependudukan Indonesia, Edisi Khusus Demografi Dan COVID-19, 2, 69-74.

Yanuarita, H. A., \& Haryati, Sri. (2021). Pengaruh Covid-19 Terhadap Kondisi Sosial Budaya Di Kota Malang Dan Konsep Strategis Dalam Penanganannya. Jurnal Ilmiah Widya Sosiopolitika, 2(2), 58-72. https://doi.org/10.24843/jiwsp.2020. v02.i02.p01 